\title{
Analisis Faktor-Faktor Yang Mempengaruhi Perilaku Pembelian Produk Kosmetik Ramah Lingkungan
}

\author{
Martha $^{1}$, Mohamad Trio Febriyantoro ${ }^{2}$ \\ Universitas Universal \\ ${ }^{1}$ marthavalentina99@gmail.com \\ ${ }^{2}$ mtriofeb@gmail.com
}

\begin{abstract}
ABSTRAK
Permasalahan lingkungan hidup dan lingkungan sosial semakin kompleks, beberapa dampak yang ditimbulkan dari kerusakan lingkungan yaitu pemanasan global dan penipisan lapisan ozon, manusia bertanggung jawwab penuh atas kerusakan lingkungan tersebut, pentingnya peranan dari dunia bisnis untuk membentuk pola konsumsi masyarakat saat ini, penggunaan kosmetik ramah lingkungan disinyalir dapat mengurangi kerusakan lingkungan yang akan berdampak bagi lingkungan. Tujuan dari penelitian ini adalah untuk mengetahui faktor-faktor yang mempengaruhi perilaku pembelian produk kosmetik ramah lingkungan di Batam. Penelitian ini dilakukan pada konsumen Batam yang merupakan pengguna produk kosmetik ramah lingkungan. Metode pengambilan sampel yang digunakan adalah purposive sampling. Sebanyak 132 kuesioner yang dapat digunakan dianalisis dalam empat hipotesis dengan menggunakan Statistical Package for Social Science Software versi 25. Dari hasil penelitian tersebut ditemukan bahwa kesediaan untuk membayar lebih pada produk ramah lingkungan merupakan faktor dominan yang mendorong perilaku konsumen dalam membeli produk kosmetik ramah lingkungan. Sedangkan rasa kepedulian terhadap lingkungan, norma pribadi dan nilai yang dirasakan tidak berpengaruh signifikan terhadap perilaku pembelian produk kosmetik ramah lingkungan.
\end{abstract}

Kata kunci: Perilaku Pembelian, Produk Kosmetik

\begin{abstract}
Environmental and social environmental problems are increasingly complex, some impacts arising from environmental damage are global warming and depletion of the ozone layer, humans are fully responsible for the environmental damage, the important role of the business world to shape the current consumption patterns of society, the use of environmentally friendly cosmetics allegedly can reduce environmental damage that will have an impact on the environment. The purpose of this study is to determine the factors that influence the purchasing behavior of environmentally friendly cosmetic products in Batam. This research was conducted on Batam consumers who are users of environmentally friendly cosmetic products. The sampling method used was purposive sampling. A total of 132 questionnaires that can be used were analyzed in four hypotheses using Statistical Package for Social Science Software version 25. From the results of the study it was found that willingness to pay more for environmentally friendly products was the dominant factor driving consumer behavior in buying environmentally friendly cosmetic products. While the sense of concern for the environment, personal norms and perceived value does not significantly influence the buying behavior of environmentally friendly cosmetic products.
\end{abstract}

Keyword: Purchasing Behavior, Cosmetic Products.

Naskah diterima: 29 Juli 2019, direvisi: 27 Agustus 2019, diterbitkan: 16 September 2019

ISSN: 2355-0295, e-ISSN: 2549-8932

http://ejournal.bsi.ac.id/ejurnal/index.php/ecodemica 


\section{PENDAHULUAN}

Perkembangan bisnis industri semakin pesat diiringi dengan meningkatnya permasalahan lingkungan hidup dan lingkungan sosial yang semakin kompleks. Kerusakan lingkungan hidup yang semakin parah telah memancing keprihatinan yang berakibat pemanasan global, penipisan lapisan ozon, dan disertifikasi. Manusia sebagai subjek yang memanfaatkan segala potensi dalam dunia bisnis memegang peranan yang penting dalam membentuk suatu lingkungan bisnis yang bersahabat dengan lingkungan (environmentally friendly). Perubahan iklim akibat pemanasan global dan kerusakan lingkungan merupakan tantangan yang serius dihadapi oleh manusia di abad 21. Di samping itu, sebagai bentuk kepedulian perusahaan dalam melestarikan lingkungan demi masa depan generasi yang akan datang, para produsen atau perusahaan juga menerapkan sustainable development atau pembangunan berkelanjutan.

Pebisnis merupakan pemangku kepentingan dalam pembangunan berkelanjutan. Dunia usaha harus didorong untuk berperan menciptakan ekonomi hijau (green economy). Model bisnis inklusif dan berkelanjutan, serta pemerintahan yang kuat dengan kebijakan yang prolingkungan akan memberi solusi transformatif menyelamatkan bumi. Kondisi seperti ini menuntut pemasar untuk hati-hati ketika keputusan yang diambil melibatkan lingkungan. Perhatian terhadap isu-isu lingkungan terlihat nyata dari meningkatnya pasar yang peduli lingkungan (Laroche, Bergeron, \& Forleo, 2001). Pembahasan mengenai isu lingkungan di negara-negara maju telah diawali dan dikembangkan sejak tahun 1990an yang menyatakan bahwa kebiasaan dan perilaku pembelian konsumen saat ini diarahkan kepada isu pemeliharaan lingkungan. Penyadaran dalam masalah lingkungan atau disebut gerakan sayangi bumi ini juga berlaku di dunia kecantikan. Memilih kosmetik dengan kandungan yang aman dan kemasan yang tepat adalah salah satunya. Peningkatan penjualan dan peluang yang terjadi pada industri kosmetik menyebabkan persaingan yang semakin ketat.

Keputusan pembelian merupakan suatu tindakan keputusan konsumen dalam membeli dan menggunakan suatu produk sesuai dengan kebutuhan dan kemampuannya. Walaupun banyak keputusan pembelian melibatkan hanya satu pengambilan keputusan, keputusan yang lain mungkin melibatkan beberapa konsumen yang memerankan peran, pencetus ide, pemberi pengaruh, pengambil keputusan, pembeli dan pemakai. Di sini tugas pemasar adalah mengidentifikasi peserta pembelian lain, kriteria pembelian mereka dan pengaruh mereka terhadap pembeli pemberi pengaruh, pengambil keputusan, pembeli dan pemakai. Tugas pemasar lainnya adalah mengidentifikasi peserta pembelian lain, kriteria pembelian mereka dan pengaruh mereka terhadap pembeli (Sunyoto, 2013). Berbagai teori perilaku pelanggan dan pemasaran menyatakan bahwa kebutuhan manusia tidak saja dipengaruhi oleh motivasinya, melainkan juga hal-hal eksternal, seperti budaya, sosial, dan ekonomi. Keputusan pembelian dan pilihan produk seringkali dipengaruhi oleh dorongan-dorongan yang sifatnya psikologis. Produk memang tidak dirancang untuk memenuhi kebutuhan fungsionalnya saja, namun juga memuaskan kebutuhan sosial dan psikologi (Sunyoto, 2013).

Generasi millennial berbeda dengan populasi pada umumnya terkait dengan kesadaran mereka akan lingkungan (Sheahan, 2005), preferensi yang lebih kuat (Smith, 2010) dan kesediaan untuk membeli produk ramah lingkungan (Rogers, 2013). Penelitian yang dilakukan oleh Paul et al., (2015) dan Geetika et al., (2017) menyatakan bahwa personal norms memiliki hubungan yang signifikan dengan niat. Konsuumen saat ini mendapatkan informasi produk dengan mudah karena menggunakan 
internet sebagai sumber informasinya (Febriyantoro \& Arisandi, 2018)

Pembelian hijau pada produk ramah lingkungan di India namun menurut Chaudary (2018) dan Khare (2015) menyatakan bahwa personal norms tidak berpengaruh secara signifikan terhadap niat beli kaum millennial pada produk hijau.Berdasarkan latar belakang tersebut, maka analisis tentang "FaktorFaktor yang Memengaruhi Perilaku Pembelian Produk kosmetik (Green Cosmetic) Ramah Lingkungan di Batam" menjadi menarik untuk dikaji.

\section{KAJIAN LITERATUR}

\section{Environmental Concern (EC)}

Kepedulian lingkungan mengacu pada reaksi emosional konsumen seperti kekhawatiran, ketidaksukaan, dan belas kasih terhadap masalah lingkungan (Milfont \& Gouveia, 2006; Yeung, 2004). Orang yang memiliki pengetahuan tentang lingkungan dan kekhawatiran cenderung akan memiliki sikap yang positif terhadap produk lingkungan (Karatu, V.M.H. , Mat, N.K.N., 2014). Seperti kasus dalam beberapa produk organik, konsumen bersedia membayar harga yang lebih tinggi untuk mendapatkan produk (Loureiro, et al (2002). Kemudian menurut $\mathrm{Hu}$, et al (2010) Kepedulian lingkungan mengacu pada sejauh mana seseorang sadar akan masalah mengenai lingkungan, berupaya mendukung penyelesaiannya, dan menunjukkan kesediaannya untuk berkontribusi dalam penyelesaian masalah lingkungan.

\section{Personal Norms (PN)}

Norma pribadi mengacu pada standar moral individu dan kewajiban untuk terlibat dalam perilaku prihatin terhadap kerusakan lingkungan (Moser, 2015). Norma subjektif juga disebut sebagai norma normatif, yaitu bagian dari keyakinan yang menentukan pemikiran individu tentang perilaku individu dalam menerima sebuah perilaku tertentu mengenai perilaku terkait, misalnya mengonsumsi produk halal (Lada, et al (2009). Norma pribadi dibuat ketika orang memasukkan norma sosial kedalam sistem nilai pribadi mereka.

\section{Perceived Value (PV)}

Nilai yang dirasakan adalah pendapat konsumen tentang nilai produk atau layanan berdasarkan evaluasi utilitasnya (Chen dan Chang, 2012). Nilai yang dirasakan memainkan peran yang penting dalam menentukan proses pengambilan keputusan konsumen Dodds, et al dan Monroe (2014) dan menentukan niat pembelian dan perilaku merek (Chen dan Chang, 2012; Chiu, Lee, dan Chen, 2014; Ng et al., 2018; Yadav dan Pathak, 2017). Konsumen akan mengevaluasi biaya dan manfaat secara subjektif ketika mereka membeli suatu produk. Mereka cenderung lebih membeli produk jika mereka merasa bahwa mereka dapat memeroleh lebih banyak manfaat dari produk tersebut (Swait dan Sweeney, 2000). Karena nilai yang dirasakan lebih penting saat ini, perusahaan dapat meningkatkan niat pembelian konsumen melalui nilai produk (Steenkamp dan Geyskens, 2006).

\section{Willingness To Pay (WTP)}

Jika dibandingkan dengan produk tradisional, produk hijau ditemukan lebih mahal karena biaya tinggi yang terlibat dalam produksi dan pemrosesan produk (Ling, 2013). Keinginan konsumen membayar sejumlah uang tertentu untuk produk produk yang ramah lingkungan lebih disebabkan karena kepedulian mereka akan permasalahan lingkungan (M. Laroche et al., 2001).

\section{Green Purchasing Behavior}

Green Purchasing adalah metode dimana pertimbangan lingkungan dan sosial yang diambil dengan bobot yang sama dengan kriteria harga, ketersediaan, dan kinerja yang digunakan untuk membuat keputusan pembelian. Green Purchasing meminimalkan dampak lingkungan dan sosial yang negatif melalui penggunaan produk ramah lingkungan. Pembelian hijau merupakan perilaku yang berupaya untuk mengidentifikasi dan mengurangi 
dampak lingkungan dan memaksimalkan efisiensi sumber daya dengan membuat keputusan pembelian melalui penggunaan produk ramah lingkungan (Yeoman, 2007).

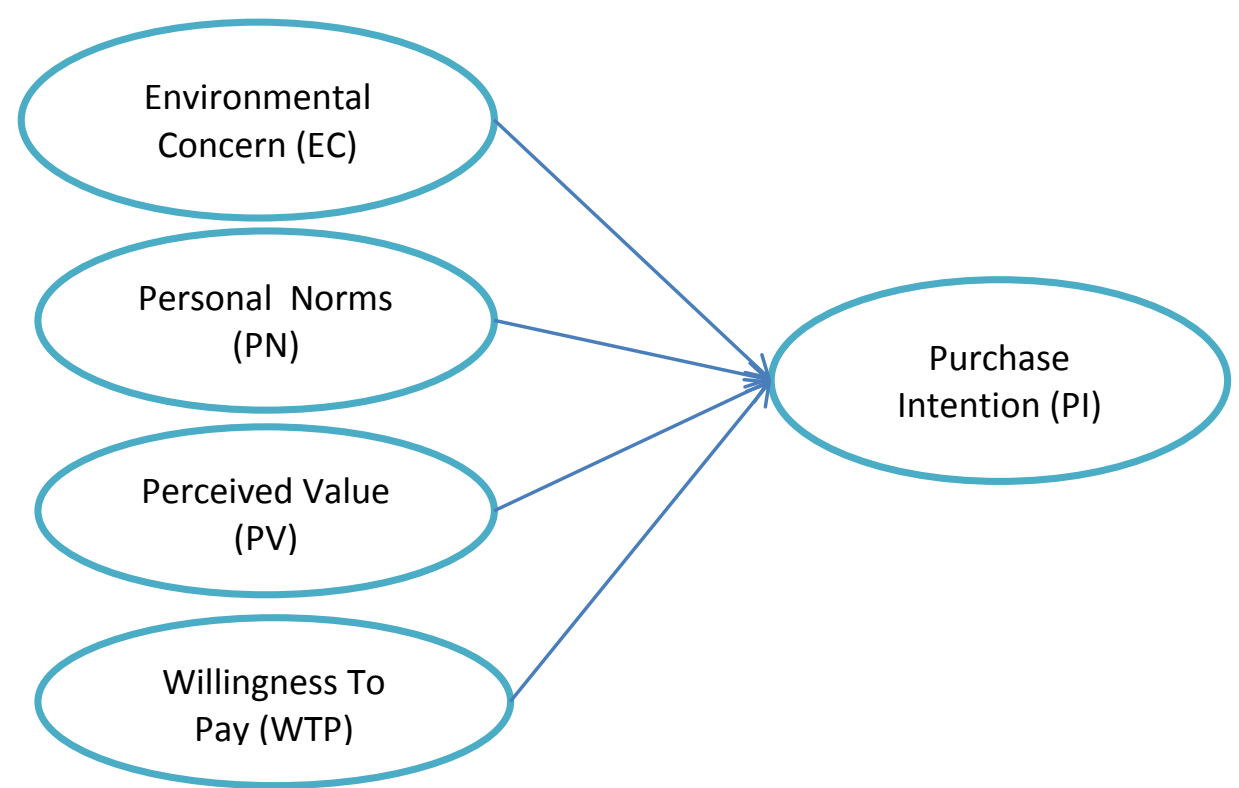

Gambar 1. Model Penelitian

\section{METODE PENELITIAN}

Ditinjau dari jenis datanya, pendekatan penelitian yang digunakan dalam penelitian ini adalah metode pendekatan kuantitatif, yaitu metode penelitian yang berlandaskan pada filsafat positivism yang digunakan untuk meneliti populasi atau sampel tertentu (Sugiyono, 2007). Populasi dalam penelitian ini adalah semua pengguna produk ramah lingkungan di Batam dengan sampel mahasiswa/i pelanggan kosmetik ramah lingkungan yang membeli produk The Face Shop, Eco Vert, The Body Shop, Estee Lauder, L'Occitane, Oriflame.

Teknik pengumpulan data dalam penelitian ini adalah dengan metode pengisian kuesioner secara online. Dalam penelitian ini, peneliti menggunakan dua sumber data yaitu data primer dan data sekunder. Data tersebut menggunakan analisis SPSS 25. Analisis regresi digunakan untuk menganalisis variabel prediktor yang mempengaruhi perilaku pembelian konsumen kosmetik hijau dan metode análisis data statistik pada penelitian ini menggunakan análisis reliabilitas dengan Cronbach's Alpha, Validitas, Multi Regresi

\section{PEMBAHASAN}

Karakteristik responden penelitian ini meliputi jenis kelamin, pekerjaan, umur, pendapatan dan frekuensi pembelian/penggunaan produk ramah lingkungan. Deskripsi dari karakteristik responden dalam penelitian ini diuraikan dibawah ini.

Tabel 1. Profil Responden

\begin{tabular}{l|ll}
\hline Jenis kelamin & Jumlah & Persentase \\
\hline Pria & 19 & $14,1 \%$ \\
Wanita & 116 & $85,9 \%$ \\
\hline
\end{tabular}




\begin{tabular}{ccc}
\hline Jumlah Pendapatan & Responden & Persentase \\
\hline$<$ Rp. $\mathbf{3 0 0 0 . 0 0 0}$ & 54 & $40 \%$ \\
Rp. 3.000.000-Rp. $\mathbf{5 0 0 0 . 0 0 0}$ & 69 & $51,1 \%$ \\
Rp. 5.000.000-Rp. 6.000.000 & 11 & 8,15 \\
Rp. 6000.000- Rp. $\mathbf{7 . 0 0 0 . 0 0 0}$ & 2 & $1,5 \%$ \\
$>$ Rp. 7.000.000 & 3 & $2,2 \%$ \\
\hline
\end{tabular}

Gambar 2. Jumlah Pendapatan Perbulan

\section{Uji Validitas}

Dari hasil uji validitas untuk masingmasing variabel pada penelitian dapat dilihat, bahwa 25 item pertanyaan pada variabel penelitian ini dinyatakan semuanya valid. Karena semua loading factor pada masing-masing item variabel memiliki nilai $\geq 0.5$.

\section{Uji Reliabilitas}

Reliabilitas dari masing-masing 4 prediktor (environmental concern, personal norms, perceived value, willingness to pay) dengan menggunakan pengukuran Cronbach's Alpha dan didapatkan hasil tertinggi 0,919 dimana semuanya dinyatakan reliabel. Hal ini disebabkan karena data penelitian memiliki nilai Alpha $\geq 0,60$.

\section{Hasil Uji R, R Square dan Adjusted R Square}

Nilai adjusted $R$ square pada penelitian sebesar 0,358. Nilai tersebut menunjukan bahwa variabel independen environmental concern, personal norms, perceived value, willingness to pay dapat menjelaskan variabel dependen purchasing behavior sebesar $35 \%$. Sisanya $65 \%$ dipengaruhi oleh variabel lain. perkiraan variabel lain yang akan mempengaruhi antara lain social influence ( Sinnappan \& Rahman, 2012; Wahid et al, 2010), perceived environmental responsibility (Lee, 2009), perceived self image (Majid et al, 2014), governments role (Sinnappan \& Rahman, 2011; Mei et al., 2012).

\section{Tabel 2. Hasil Uji R Square}

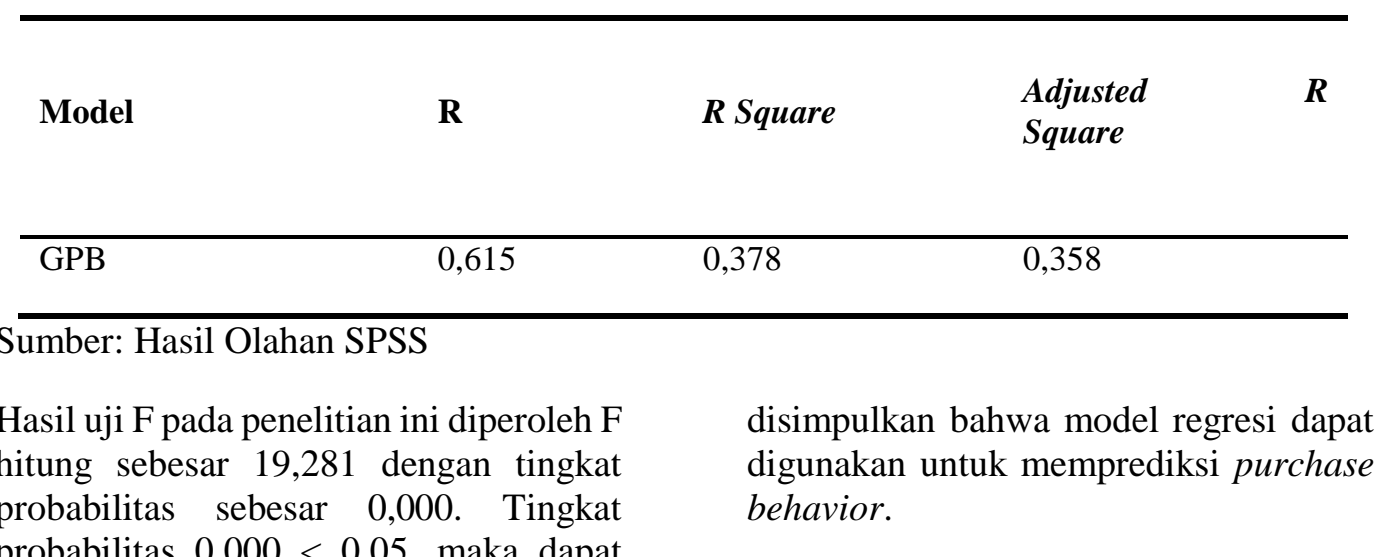
probabilitas $0,000<0,05$, maka dapat 
Uji t dilakukan untuk melihat tingkat signifikansi dari masing-masing variabel independen terhadap variabel dependen.
Hasil uji dapat dilihat nilai signifikansi pada Tabel 4

Tabel 3. Hasil Uji F

\begin{tabular}{llll}
\hline Variabel Dependen & F & Sig. & Kesimpulan \\
\hline GPB & 19,281 & 0,000000 & Signifikan \\
\hline
\end{tabular}

Sumber: Hasil Olahan SPSS 25

Tabel 4. Hasil Uji t

\begin{tabular}{|c|c|c|c|c|}
\hline \multirow[t]{2}{*}{ Variabel } & $\begin{array}{l}\text { Unstandardized } \\
\text { Coefficients }\end{array}$ & \multirow[t]{2}{*}{$T$} & \multirow[t]{2}{*}{ Sig } & \multirow[t]{2}{*}{ Kesimpulan } \\
\hline & B & & & \\
\hline (Constant) & 0,671 & 2,421 & 0,017 & - \\
\hline Environmental Concern & 0,161 & 1,911 & 0,058 & $\begin{array}{l}\text { Tidak } \\
\text { Signifikan }\end{array}$ \\
\hline Personal Norms & 0,136 & 1,496 & 0,137 & $\begin{array}{l}\text { Tidak } \\
\text { Signifikan }\end{array}$ \\
\hline Perceived Value & 0,36 & 1,443 & 0,151 & $\begin{array}{l}\text { Tidak } \\
\text { Signifikan }\end{array}$ \\
\hline Willingness To Pay & 0,365 & 4,460 & 0,00 & Signifikan \\
\hline
\end{tabular}

Sumber: Hasil Olahan SPSS 25

\section{Uji Multikolonieritas}

Multikolonieritas adalah suatu keadaan dimana satu atau lebih variabel independent terdapat korelasi atau hubungan dengan variabel independen lainnya atau dengan kata lain satu atau lebih variabel independen merupakan satu fungsi linear dari variabel independen lainnya (Ghozali, 2011). Pada penelitian ini dilihat hasil pengujian multikolinearitas menunjukkan bahwa semua variabel tidak terdapat multikolinearitas dikarenakan nilai VIF pada setiap variabel lebih kecil dari 10 dan nilai tolerance lebih besar dari 0,1 .

Tabel 5. Hasil Uji Multikolinieritas

\begin{tabular}{lllll}
\hline \multirow{2}{*}{ Variabel } & \multicolumn{1}{c}{ Collinearity } & \\
& Statistics & \multicolumn{2}{c}{ Kesimpulan } \\
\cline { 2 - 3 } & Tolerance & VIF & \\
\hline Environmental Concern & 0,690 & 1,449 & Tidak terjadi multikolinearitas \\
Personal Norms & 0,592 & 1,688 & Tidak terjadi multikolinearitas \\
Perceived Value & 0,549 & 1,820 & Tidak terjadi multikolinearitas \\
Willingness To Pay & 0,730 & 1,370 & Tidak terjadi multikolinearitas
\end{tabular}

\section{Uji Heteroskedasitas}

ISSN: 2355-0295, e-ISSN: 2549-8932

http://ejournal.bsi.ac.id/ejurnal/index.php/ecodemica 
Hasil pengujian heteroskedastisitas dapat dilihat dari penyebaran data terlihat acak dan tidak membentuk pola khusus maka dapat dikatakan bahwa tidak terjadi gejala heterokedastik dalam variabel bebas yang akan diteliti. Sebaliknya apabila ketika melakukan uji scatter plot terjadi pola data yang mengumpul dan membentuk suatu pola khusus maka dapat dikatakan data tersebut mengalami gejala $\mathrm{h}$ dibawah $\mathrm{i}$ menyebar acak dan titik-titik tersebut tidak membentuk suatu pola tertentu. sehingga hasil uji tidak terjadi heteroskedasitas.

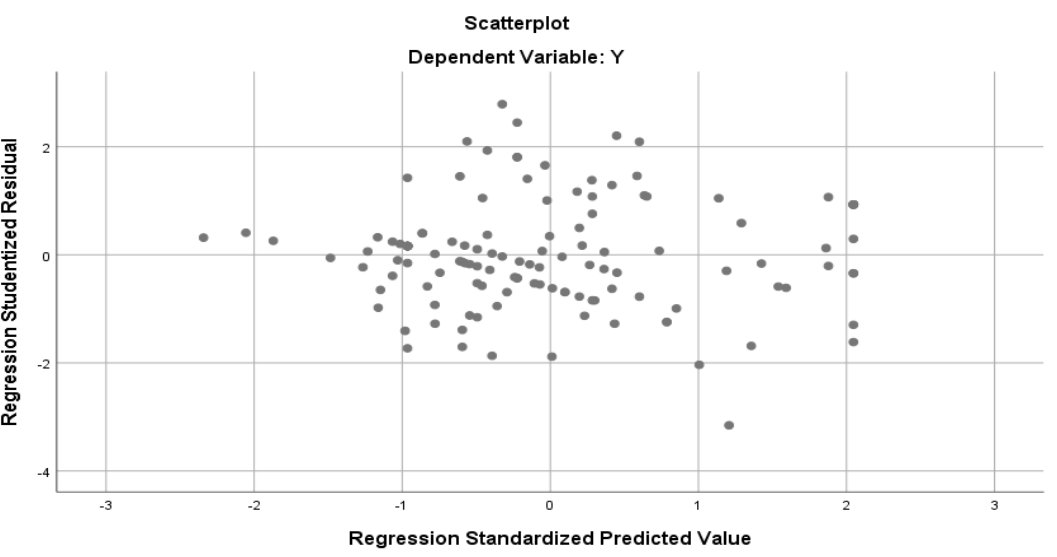

Gambar 3. Ujı Heterokestasdisitas

\section{PENUTUP}

Dari hasil penelitian dan pembahasan diatas, dapat disimpulkan bahwa Mayoritas konsumen meyatakan bahwa sebagian besar masyarakat merasa kondisi lingkungan Batam masih tergolong ramah lingkungan. Sehingga pada hasil penelitian ini, kesadaran untuk melindungi lingkungan dan rasa keseriusan terhadap masalah lingkungan menunjukkan hasil yang tidak berpengaruh dan tidak signifikan terhadap keinginan konsumen dalam membeli produk ramah lingkungan. kemudian, berdasarkan hasil wawancara lapangan cara masyarakat Batam dalam menjaga serta melestarikan lingkungan lebih mengarah pada memilah sampah berdasarkan jenisnya dan mendaur ulang sampah bekas yang dapat dimanfaatkan kembali lagi. Selain itu, ada juga BBM ramah lingkungan bagi pengendara sepeda morot atau mobil yang merupakan salah satu untuk menjaga lingkungan Batam selalu sehat dan bersih.
Kesediaan konsumen untuk membayar lebih pada produk ramah lingkungan memiliki pengaruh positif dan signifikan terhadap keinginan konsumen dalam membeli produk ramah lingkungan. Konsumen menyatakan bahwa mereka rela membayar lebih pada kosmetik yang berbahan alami yang aman digunakan karena cocok atau tidak produk tersebut tidak akan memberikan efek samping yang besar. Sikap tersebut yang mendorong terbentuknya perilaku konsumen dalam membeli produk ramah lingkungan dan kesediaan konsumen untuk membayar lebih (willingness to pay) pada produk ramah lingkungan. Namun, di sisi lain hasil dari produk ramah lingkungan tidak seketika pakai terlihat perbedaannya. untuk pemakaian produk ramah lingkungan harus sabar dan konsisten. Serta mayoritas konsumen menyatakan bahwa sebagian besar masayarakat merasa kondisi lingkungan Batam masih tergolong ramah lingkungan. Sehingga pada hasil penelitian ini, perceived value dan 
personal norms tidak berpengaruh signifikan terhadap keinginan konsumen dalam membeli produk ramah lingkungan. Konsumen memutuskan membeli sebuah produk dilandaskan pada pemikiran rasional dan pemikiran irasional (emosi) (Febriyantoro, 2016)

Bagi peneliti selanjutnya yang ingin mengembangkan penelitian ini, dapat disarankan untuk memperluas objek penelitian tidak hanya di bidang kosmetik saja tapi bisa di bidang elektrik, pangan dan produk lainnya yang berkaitan dengan green. Kemudian, Dalam hal pemilihan sampel responden dapat difokuskan pada karyawan-

\section{REFERENSI}

Chen, Y. S., \& Chang, C. H. (2012). Enhance green purchase intentions: The roles of green perceived value, green perceived risk, and green trust. Management Decision, 50(3), 502-520.

https://doi.org/10.1108/002517412 11216250

Chiu, Y. T. H., Lee, W. I., \& Chen, T. H. (2014). Environmentally responsible behavior in ecotourism: Antecedents and implications. Tourism Management, 40, 321329. https://doi.org/10.1016/j.tourman.2 013.06.013

Dodds, W. B., Monroe, K. B., Grewal, D., Dodds, B., \& Monroe, B. (2014). of Information Buyers ' Evaluations. Journal of Marketing Research, 28(3), 307-319. https://doi.org/10.2307/3172866

Febriyantoro, M. T. (2016). Pemikiran irasional para perokok. EKSIS, XI(2), 1907-7513.

Febriyantoro, M. T. (2018). The Role Of Entrepreneurial Campus In Establishing Of Students' karyawan perkantoran. Dengan melakukan penelitian ini pada karyawan perkantoran diharapkan dapat memberikan informasi baru bagi pemasar produk ramah lingkungan pada karyawan perkantoran. Upaya meningkatkan konsumsi produk ramah lingkungan pada karyawan perkantoran diharapkan dapat memberi pengaruh postif bagi budaya perusahaan di tempat mereka bekerja. Ketika suatu perusahaan telah membudayakan konsep go green atau ramah lingkungan, hal ini tentunya akan mebawa dampak positif yang lebih luas kepada masyarakat dan lingkungan dimana perusahaan tersebut beroperasi (Febriyantoro,2018)

Entrepreneurial Mindset and Entrepreneurial Spirit. International Conference of Econimic Studies, 141-146.

Febriyantoro, M. T., \& Arisandi, D. (2018). Pemanfaatan Digital Marketing Bagi Usaha Mikro, Kecil Dan Menengah Pada Era Masyarakat Ekonomi Asean, 1(2), 61-76.

Hu, H. H., Parsa, H. G., \& Self, J. (2010). The dynamics of green restaurant patronage. Cornell Hospitality Quarterly, 51(3), 344-362. https://doi.org/10.1177/193896551 0370564

Karatu, V.M.H. , Mat, N.K.N., 2014. (2014). A New Model Of Green Purchase Intention and its Derivatives: Confirmatory Factor Analysis Validation Of Constructs, 261-268.

Kwe Lu, T., Majid, N. F. N. A., Harun, N. H., \& Othman, N. (2014). Assessing the Variables That Influence the Intention of Green Purchase. Journal of Social Science Research, 2, 2289-4977.

Lada, S., Harvey Tanakinjal, G., \& Amin, H. (2009). Predicting intention to choose halal products 
using theory of reasoned action. International Journal of Islamic and Middle Eastern Finance and Management, 2(1), 66-76. https://doi.org/10.1108/175383909 10946276

Lee, K. (2009). Gender differences in Hong Kong adolescent consumers' green purchasing behavior. Journal of Consumer Marketing, 26(2), 8796.

https://doi.org/10.1108/073637609 10940456

Ling, C. Y. (2013). Consumers' purchase intention of green products: an investigation of the drivers and moderating variable. Elixir Marketing Mgmt. 5, 57(A), 1450314509.

Loureiro, M. L., McCluskey, J. J., \& Mittelhammer, R. C. (2002). Will consumers pay a premium for ecolabeled apples. Journal of Consumer Affairs, 36(2), 203-219. https://doi.org/10.1111/j.17456606.2002.tb00430.x

M. Laroche, J. Bergeron, G.BarbaroForleo, Laroche, M., Bergeron, J., \& G.Barbaro-Forleo. (2001). Targeting consumers who are willing to pay more for environmentally friendly products. Journal of consumer marketing, 18 (6), 503-520. Journal of Consumer Marketing, 18(6), 503-520. https://doi.org/10.1108/EUM00000 00006155

Mei, O. J., Ling, K. C., \& Piew, T. H. (2012). The antecedents of green purchase intention among malaysian consumers. Asian Social Science, $\quad 8(13), \quad 248-263$. https://doi.org/10.5539/ass.v8n13p 248

Milfont, T. L., \& Gouveia, V. V. (2006). Time perspective and values: An exploratory study of their relations to environmental attitudes. Journal of Environmental Psychology,

26(1), 72-82.

https://doi.org/10.1016/j.jenvp.200 6.03 .001

Moser, A. K. (2015). Thinking green, buying green? Drivers of pro Environmental purchasing behavior. Journal of Consumer Marketing, 32(3), 167-175. https://doi.org/10.1108/JCM-102014-1179

Ng, M., Law, M., \& Zhang, S. (2018). Predicting purchase intention of electric vehicles in Hong Kong. Australasian Marketing Journal, , 1-9.

https://doi.org/10.1016/j.ausmj.201 8.05.015

Steenkamp, J. E. M., \& Geyskens, I. (2006). the Perceived Value of Web Sites. Journal of Marketing, 70(July), 136-150.

Sugiyono. (2007). Metode Penelitian Kuantitatif Kualitatif dan $R \& D$. Bandung: Alfabeta.

Swait, J., \& Sweeney, J. C. (2000). Perceived value and its impact on choice behavior in a retail setting. Journal of Retailing and Consumer Services, $\quad 7(2), \quad 77-88$. https://doi.org/10.1016/S09696989(99)00012-0

Wahid, N. A., Rahbar, E., \& Shyan, T. S. (2010). Factors Influencing The Green Purchase Behavior of Enviornmental Related Volunteers in Penang.

Yadav, R., \& Pathak, G. S. (2017). Determinants of Consumers' Green Purchase Behavior in a Developing Nation: Applying and Extending the Theory of Planned Behavior. Ecological Economics, 134, 114122.

https://doi.org/10.1016/j.ecolecon. 2016.12.019 
Yeung, S. P. M. (2004). Teaching approaches in geography and students' environmental attitudes. Environmentalist, 24(2), 101-117. https://doi.org/10.1007/s10669004-4801-1

\section{BIODATA PENULIS}

Martha adalah mahasiswa Universitas Universal pada Program Studi Manajemen konsentrasi Manajemen Pemasaran

Mohamad Trio Febriyantoro, adalah dosen Program Studi Manajemen Universitas Universal, fokus penelitian penulis antara lain Manajemen Pemasaran, Kewirausahaan dan Manajemen Inovasi. 